\title{
Analysis on the Influence of COVID-19 on International Financial Market Integration and the Improvement of Climate Finance
}

\begin{abstract}
Yaqi Zhang
The Ohio State University, Columbus, Ohio, USA

Corresponding author. Email: gaoming@cas-harbour.org

ABSTRACT

The Coronaviruses virus become the most concerned topic nowadays since it is first discovered by people. Whether it is in terms of health or economy, the severity of the Coronaviruses virus brings unprecedented blows to the economies of many countries, but it only has a negative impact on the economy, or it also plays a role in promoting a certain aspect of the economy. In this article, a lot of data compiled by the World Health Organization, such as unemployment rate and prevalence rate, national GDP development data compiled by the World Bank website, as well as stock development trends, AI, climate financing strategies and national mutual aid relations are used. In addition, it can be concluded that the Coronaviruses virus has a part of the guiding role of the economy, that is, the Coronaviruses virus is an important propeller of global economic unification and progress in climate financing.
\end{abstract}

Keywords: Influence of COVID-19, International Financial Market Integration, climate finance, improvement

\section{INTRODUCTION}

Coronaviruses are a broad group of viruses that can cause illness. Patients' symptoms range from a normal cold to severe lung infections like Middle East Respiratory Syndrome (MERS) and Severe Acute Respiratory Syndrome (SARS). The new coronavirus $(\mathrm{nCoV})$ is a coronavirus that is not discovered in humans. This time, a novel coronavirus was discovered in Wuhan, China, 2019-nCov, is also called COVID-19. COVID-19 impacted the whole world tremendously. Respiratory symptoms, fever, cough, shortness of breath, and difficulty breathing are all common signs of infection, depending on the type of virus and the patient's physical condition. The infection can cause pneumonia, severe acute respiratory syndrome, renal failure, and even death in more severe cases. According to the World Health Organization's calculations, confirmed cases are $207,784,507$, deaths are 4370,428, the death rate after contracting the new coronavirus is about $0.2 \%$ for now [1]. However, the dangers of it not only represent how high the fatality rate is or how easy it can spread but are also represented the shock of the economy. The pandemic changed people's work-style from on site to remote working, and damaged lots of traditional businesses. The emergence of the pandemic is hastened by issues and inconsistencies in many nations' economic structures, and the debt problem becomes the push for another crisis, with the inevitable outcome of economic depression. However, there are still several good aspects from the COVID-19. By the massive decline of traditional local companies around the world, international finance is promoted in this pandemic. The climate finance is improved during this critical time as well.

\section{THE ANALYSIS OF INTERNATIONAL FINANCIAL MARKET\& CLIMATE FINANCE}

\subsection{Covid-19 big impact on the world economy}

First and foremost, the COVID-19 virus has a significant influence on global banking. As a result, the global GDP growth rate in 2020 is the lowest from 2008, China increased 2.3\%, United State decreased 3.5\%, Japan increased $0.3 \%$, Germany decreased $4.9 \%$... [2]. Since epidemic start, the disease spreads quickly. China, the United States, Japan, South Korea, the United Kingdom and other countries formed ten key disaster 
areas. More than $60 \%$ of global GDP is generated in these main catastrophe regions, and the import and export industry is likewise a major national center. Its purpose is to link the economic development of many nations and to extinguish the momentum of economic recovery that is going to emerge, accounting for more than half of the entire size. The impact of the COVID-19 virus on international finance is overwhelmingly high. The global financial market is turbulent, and the stagnation of production and business activities has a direct impact on the labor market.

The unemployment rate and social instability increases, the productivity falls as well. Bond yields, oil, and stock prices plummeted. The public's fear level regarding this occurrence is higher than it was during the financial crisis of 2008. The stock markets in several countries tripp circuit breakers because indications of economic revival vanished. In the United States, there are several economic circuit breakers, and many stock markets plummeted, formed the most significant drop. Both worldwide oil and gold prices is trending lower. Until March, the price of gold is on the rise, but as investors become more concerned about the danger of a worldwide economic crisis, the price of gold is plunged. The same is true for oil prices. According to Statista, the number of coronavirus cases worldwide as of July 27, 2021, is raised to more than 206 million [3]. This means more than $2.4 \%$ of the world population have or currently suffering from this disease.

It is easy to see that how the economy would be suffering because of this huge decrease in the labor population. The surge of unemployment leading to bear in the stock market and financial fields. The Dow Jones index is decreased by over 30\% from February 2020 to April 2020 [4]. Many companies bankrupted because of the increasing debt in the critical time. Lots of businesses are hiring workers due to the lack of capable labor. Consumers decreases their purchasing costs as a result of the outbreak, and they are concerned about the spread of the new crown virus. People are being advised not to go out by the government, which has a catastrophic effect on the hotel and catering industries. It is possible that economic growth may come to a halt.

Overall, the new crown pneumonia epidemic has an all-round impact on the world economy and causes major turbulence in the global capital market. Despite the fact that the epidemic has a significant impact on the global economy, the new smart technologies, new products, remote home offices, online social networking, and other new business formats that the epidemic's prevention and control spawns may become new economic growth points around the world. People must be as "normal" as possible throughout these unusual eras for a variety of reasons, and they must be prepared for typical everyday activities. The capacity to employ such information technology (IT) approaches will certainly expand as we all learn to operate more remotely and have meetings virtually when necessary [5].

\subsection{Opportunities in Financial Globalization}

With all these declines in the finance field and economy, there are several opportunities raising as well. Financial globalization will increase the probability and intensity of financial risks when the economic conditions and development trends of various countries are not uniform. Because the financial crises it causes can be infectious and self-reinforcing, the fundamental problem with the domestic financial sector is not been significant enough to trigger unrest. However, there are also the consequences of the financial system collapsing as a result of external market shocks. International financial integration is a process in which global economies' financial markets are intertwined. For example, when some local companies collapsed, there is empty room for new markets.

During the pandemic, only big companies which have sufficient cash flows, are able to expand their cooperation and fill in the newly emerged blank market. Especially in international business, where can generate high benefits by lower labor cost compared to domestic business. They can spread their products to much more new customers and capture the market. Furthermore, more capital recognized this trend, investments flow from the old domestic business to newer international ones. Leading to increase equity growth among international businesses. As Steven Altman said, "Strengthening global connectivity and financial integration will help the world get rid of the new crown epidemic faster, because countries with better connectivity to international flows tend to have stronger economic growth." Such a process improved international financial integration. Marketing strategies is influenced by online conferences, education, entertainment, medical care, and new e-commerce and consumption patterns

Artificial intelligence is promoted and popularized as a result of the epidemic, and the global digital industry's development is accelerated. Digitalization and the use of information and communication technology will be critical not only to protect but also to administer the planet after COVID-19. Artificial intelligence (AI), Big Data, 5G communications, cloud computing, and blockchain are examples of new technologies that can help to enhance the environment while also protecting people and economies [6] In developing sectors such as $5 \mathrm{G}$, big data, artificial intelligence, and cloud computing, the globe will collaborate under such huge conditions, injecting new impetus into sustainable global growth.In the process of organizing and implementing $5 \mathrm{G}$ research and 
development, broadband mobile communication projects focused the enthusiasm of all parties, strengthened the construction of innovation chains and industrial chains, and gave full play to the advantages of universities, enterprises, and research institutes, in order to jointly overcome the impact of the epidemic, through standardized promotion platforms, industrial collaboration platforms, and international promotion platforms, the overall layout and coordinated promotion forms a new innovation system for the operation of the large corps, which effectively guarantees the realization of special targets and is conducive to the further development of future mobile communications. Laid a solid foundation. Broadband mobile communications initiatives, on the other hand, emphasize open collaboration.

Many European Union 5G R\&D organizations have a tendency to create internationally uniform standards. Enterprises from many nations contribute to the development of global mobile communication standards and industries by participating in research and development of key projects. Various nations' research institutes are stepped up their efforts to create manufacturing, education, and research platforms, break through the integration of core technologies and important sectors, and support the construction of a worldwide unified $5 \mathrm{G}$ network. Therefore, with the goal of $5 \mathrm{G}$ global unification and shared industry economies of scale, countries are conducted many scientific and technological seminars and exchanges to jointly realize the urgent needs of global digital industry development during the epidemic and promote the integration of digitalization and economic integration.

\subsection{Climate Financing in Pandemic}

Climate financing is another thing that is promoted during the pandemic. Modern medicine proves that there is a close connection between infectious transmission and climate change. Climate financing refers to financial resources that are provided or mobilized to assist poor nations in reducing and/or avoiding greenhouse gas emissions, as well as building resilience and adapting to the different consequences of climate change. Climate change can make infectious diseases easier to spread and spread in four ways: changing pathogens, changing the way the disease spreads, affecting the immune system of animals and humans, and affecting the ecological environment. The trajectory of global warming is not slowed down, but rather accelerated. Due to the public and worldwide character of climate change initiatives, all parties must collaborate. Financial assistance is critical to these efforts. Several financial institutions, government ministries, other organizations, and the private sector at home and abroad are providing funds to support climate change activities in response to the new crown epidemic.
Faced with the huge funding gap caused by the epidemic, climate investment and financing activities can play a powerful role in financial support. The formulation of policies and standards related to climate investment and financing can regulate and guide the precise flow of funds to green and low-carbon fields, promote the development of low-carbon and climate-adaptive industries, and provide carriers for the flow of funds. Renewable energy, low-carbon transportation, low-carbon buildings, climate adaptability.

Climate funding must be delivered in the form of grants, because loans would only worsen the current financial crisis. A gender-responsive and Human-Rights-based approach to finance is the only way to achieve revolutionary positive change [7]. By the statement from United Nations, research and reports conducted before the COVID-19 pandemic indicate that investment in climate action will be of great benefit to building a sustainable economy. According to data from the World Bank in October 2019, the world will need to invest heavily in infrastructure in the next 15 years-approximately US $\$ 90$ trillion will be invested by 2030. But these investments can be recovered. The study found that the transition to a green economy can unlock new economic opportunities and job opportunities. An average investment of 1 USD generates 4 USD. It shows that climate financing has a high prospective yield. Many nations are identified climate change as one of the major elements influencing the spread of infectious illnesses as a result of the present epidemic's effect and encouragement.

Climate change mitigation investments and funding can help to reduce global warming, reduce environmental damage, and decrease viral mutation. Therefore, further strong support for capital investment in the field of climate change mitigation. The government is in charge of increasing public investment in climate mitigation efforts by directing financial funding. Climate credit, climate insurance, climate bonds, climate funds, and other climate investment and finance mechanisms serve as conduits for capital to flow into renewable energy, low-carbon transportation, low-carbon buildings, climate adaptation, and other areas, and ensure the development of climate-friendly projects from the financial aspect runs smoothly.

However, countries do not need to wait for the global stocktake to realize that immediate action, quicker implementation, higher mitigation objectives, and revolutionary collaboration are required to address the climate emergency. Parties must explore how to enhance the Global Stocktake process so that it can serve as an effective tool for increasing climate ambition and implementation, as well as holding nations responsible for their commitments and objectives [7]. In different nations, the pandemic 
enhances the role of private capital businesses in climate finance. To entice private money to engage in the climate area, establish public-private capital cooperation and other methods. It increases financing while also raising public awareness of project climate concerns. Which is conducive to private capital to attach importance to climate project investment in follow-up investment.

The pandemic decreases the automobile exhaust emissions because of the limitation of travel and commute. People generally find that lowering the emission and protect our planet is beneficial not only ecologically, but also financially. In addition to reducing emissions, improving the resilience of infrastructure can also avoid expensive maintenance costs and minimize the impact of natural disasters on the livelihoods and well-being of people, especially the most vulnerable groups, as well as on businesses and the economy. Countries recognize the need for specific climate financing mentioned in the "Paris Agreement", which calls for "making capital flows in line with the path of low greenhouse gas emissions and climate-resilient development." During the pandemic, more and more private business get benefits from the lower emission comparing to pre-pandemic. Follows the number nations that consider about add funding to climate financing and researching of clean energy are raised. These facts increase the job position and slow down the global warming. It finally leading to a sustainable, clean earth.

Guests and economic experts at the Sixth Delphi Economic Forum in Greece warns that the world economy would need at least two years to recover from the new crown pandemic, and that international collaboration is critical to resolving the present problem. In his address, Nobel Laureate in Economics Christopher Pisarides states that resuming the economy is not as simple as clicking a button, and that recovery will take two years. He also underlines the necessity of change and voiced confidence in Greece's present reform path. Barry Eichengreen, professor of economics and political science at the University of California, Berkeley, believes that this recovery will be faster than during the 2008 international financial crisis, but it will not be as easy as pressing the restart switch. The European economy is anticipated to return to normal in 2024, according to Gunter Ottinger, a former European Commission commissioner in charge of budget issues. Former European Central Bank President Jean-Claude Trichet states that the new crown crisis aids in the discovery of economic vulnerabilities and the acceleration of promising trends like as digitization. This crisis also highlights the importance of international cooperation. Although many countries are facing the risk of economic recession, at this time, countries can learn from the experience of dealing with the global financial crisis, strengthen policy coordination, and the economy will soon recover.

Simultaneously, after the economy has recovered, changes is requiring to put the country on a more stable budgetary path. The federal government will have to cut inefficient entitlement and other spending while increasing income in the most efficient way feasible. For the time being, the country's most pressing concern is to safeguard the economy from additional harm and hasten the recovery from the greatest economic crisis since the Great Depression. These suggestions are meant to assist you in achieving that objective [8].

\section{CONCLUSION}

In conclusion, although the COVID-19 impacts multiple financial areas and the whole economy. However, it is still beneficial to the integration of international finance and improves the process of climate finance. There are still more we can do to improve the future international financial market and climate finance. In order to cope with global climate change and realize the green transformation of the economy, governments and enterprises around the world should work together. At the macro level, green economy development plans formulated and launched by governments using administrative means will become an important force to guide market demand and corporate actions.

\section{REFERENCES}

[1] WHO Coronavirus (Covid-19) Dashboard. World Health Organization. Retrieved on August 18, 2021, from https://covid19.who.int

[2] GDP growth (annual\%). The world Bank. Retrieved on August 18, 2021, from https://data.worldbank.org/indicator/NY.GDP.MK TP.KD.ZG

[3] J. Elflein. Coronavirus(Covid-19) disease pandemicStatistic\& facts. Statista. 2021. Retrieved on August 18, 2021, from https://www.statista.com/topics/5994/the-coronavir us-disease-covid-19-outbreak/

[4] Dow Jones Industrial Average. MarketWatch. Retrieved on August 18, 2021, from https://www.marketwatch.com/investing/index/djia

[5] J. Chiodini. Online Learning in the time of Covid-19. Travel Med Infect Dis. 34:101669. 2020.

[6] Y. Siriwardhana, C. De Alwis, G. Gür, M. Ylianttila and M. Liyanage, The Fight Against the COVID-19 Pandemic With 5G Technologies. IEEE Engineering Management Review. 2020, 48(3): $72-84$. 
[7] Climate Action Network Briefing: Virtual SB 2021. CAN. 2021. Retrieved on August 18, 2021, from https://climatenetwork.org/wp-content/uploads/202 1/05/CAN-Briefing_-Virtual-SB-2021_May-20211.pdf

[8] J. Furman, T. Geithner, G. Hubbard, M.S. Kearney. Promoting Economic Recovery After COVID-19. The Aspen Institute- Economic Strategy Group. 2020. Retrieved on August 18, 2021, from https://www.economicstrategygroup.org/wp-conte nt/uploads/2020/11/Promoting-Economic-Recover y-After-COVID-0615-FINAL.pdf 